\section{Zdzisław Pawłowski}

Uniwersytet Mikołaja Kopernika, Toruń

zdziwpaw@umk.pl

DOI: http://dx.doi.org/10.12775/BPTh.2017.027

\section{Biblica}

et

Patristica

Thoruniensia

10 (2017) 4: 533-547

ISSN (print) 1689-5150

ISSN (online) 2450-7059

\title{
Od skargi do ufności. Narracyjna struktura Ps 6
}

\section{From Complaint to Confidence. Narrative Structure of Psalm 6}

Cierpienie nie jest bólem ${ }^{1}$.

Streszczenie. Spośród pięciu lamentacji (Ps 3-7), otwierających pierwszą księgę Psałterza (Ps 3-41) Ps jest wyjątkowy. Brakuje w nim bowiem kilku, charakterystycznych dla tego gatunku literackiego elementów. Składa się on prawie wyłącznie ze skargi i obejmującej trzy końcowe wiersze (9-11) pewności wysłuchania przez Boga. A ponieważ ta ostatnia występuje zaraz po opisie sytuacji cierpienia, dlatego przejście od skargi do ufności stanowi problem zarówno na płaszczyźnie psychologicznej, jak i teologicznej. Analiza psalmu za pomocą krytyki form, odwołująca się do tła kultycznego, nie znajduje potwierdzenia w jego treści, zdominowanej przez zmieniającą swój kształt językowy skargę. Między sytuacją cierpienia a pewnością wysłuchania dokonuje się tak radykalna zmiana w czasie, że jedynie interpretacja uwzględniająca strukturę narracyjną psalmu, może ją w pełni wyjaśnić.

Abstract. Of the five psalms that comprise the beginning of the First Book of the Psalter (Psalms 3-7) Psalm 6 exhibits exceptional character and structure. It consists only of complaint (2-8) and expression of confidence in God (9-11). On the psychological as well as the theological plane it is almost impossible by means of form-critical inquiry to explain and make sense of transition from crisis caused by suffering of the psalmist to confidence that the Lord has heard his supplication. The only way to illuminate what happened in between is to read the whole psalm through narrative lens.

1 To tytuł krótkiego eseju autorstwa Paula Ricoeura, zamieszczonego w: Filozofia osoby, Kraków 1992. Zaraz na początku zastrzega on, że celem jego rozważań nie jest wskazywanie kierunku działań psychoterapeutycznych, lecz lepsze zrozumienie ludzkiej istoty jako osoby cierpiącej, ibidem, s. 55. 
Słowa kluczowe: lamentacja indywidualna; skarga; sytuacja graniczna; apostrofa; pewność wysłuchania; struktura narracyjna.

Keywords: Individual lament; complaint; limit situation; apostrophe; expression of confidence; narrative structure.

Ckarga jest najważniejszym i często najbardziej rozbudowanym elementem pienia, spowodowanego chorobą, śmiercią, winą, walką, czy osamotnieniem² Od czasów Karla Jaspersa noszą one nazwę sytuacji granicznych ${ }^{3}$. Lamentacje wyrażają je za pomocą własnych, specyficznych obrazów, które nie bardzo pasują do sposobów, w jakich dzisiaj ludzie przedstawiają swoje dramatyczne doświadczenia ${ }^{4}$. Dodatkową trudnością w ich lekturze jest także fakt, że $z$ reguły nie podają żadnych racjonalnych rozwiązań wyjścia z sytuacji cierpienia lub przezwyciężenia go ${ }^{5}$. Na tym polu psalmy przegrywają w konfrontacji ze współczesną psychologią, oferującą różnorodne i konkretne narzędzia i techniki terapeutyczne. Większość osób w sytuacji traumy szuka wsparcia w profesjonalnej psychoterapii i nie jest świadoma, że istnieją formy poetyckie w Biblii, które mogą pomóc wypowiedzieć własne cierpienie, zrozumieć je i je wytrwale znosić. Niestety, dzisiejszy sposób życia, w którym skrzętnie ukrywa się wszelką słabość i zranienia, eksponując siłę i zaradność, sprawia, że język lamentacji staje się obcy i mało zrozumiały. Już bezpośrednie zwrócenie się do Boga w formie inwokacji, np. „Boże mój, Boże mój, czemuś mnie opuścił?” (Ps 22,1), wywołuje bardziej zażenowanie i zdziwienie niż współczucie (por. Mk 15,33-37). Wcześniejsze pokolenia wierzących sięgały po psalmy jako naturalną formę modlitwy w nadziei, że pomogą im one odkryć prawdę o sobie i nauczą przyjmować tragizm wpisany w ludzki $\operatorname{los}^{6}$. Dzisiejsi chrześcijanie, przystosowując się do panującej kultury, starają się przekonać siebie i innych, że nie potrzebują smutku ani płaczu, gdyż Bóg uczynił wszystko dobrym, a chrześcijaństwo dzięki zmartwychwstaniu Jezusa jest religią optymizmu i radości. Konsekwencją tych poglądów jest utrata umiejętności przeżywania cierpienia. Przyswojenie

\footnotetext{
2 Por. P.S. Johnston, The Psalms and Distress, s. 63nn.

3 Zob. K. Jaspers, Sytuacje graniczne, s. 186nn.

4 Por. P.S. Johnston, The Psalms and Distress, s. 63.

5 Por. Ps 88, będący od samego początku do końca skargą, pozbawioną nawet iskierki

6 Por. J.L. Mays, A Question of Identity: The Threefold Hermeneutic of Psalmody,
} nadziei. s. $87 \mathrm{nn}$. 
języka biblijnych lamentacji z ich poetyckimi środkami wyrazu może przywrócić zdolność do akceptowania zranień i zmierzenia się z ich czasami długotrwałymi skutkami ${ }^{7}$.

W odróżnieniu do bólu fizycznego, zlokalizowanego w jakiejś części lub w całym ciele, cierpienie, zdaniem Paula Ricoeura należy do tego rodzaju doznań, które wymagają wglądu w siebie, językowego sposobu wyrażenia, określenia stosunku do własnej osoby, do innych, do całości swego życia, jednym słowem, stawiają pytanie o tożsamość, o to, kim jestem w sytuacji cierpienia ${ }^{8}$. Tej egzystencjalnej problematyce odpowiada złożona struktura literacka lamentacji, wewnątrz której skarga jest tylko jednym z elementów. Stosuje ona różne środki retoryczne w zależności od swego miejsca i funkcji.

Spośród wszystkich lamentacji w księdze Psalmów, większość to pieśni błagalne jednostek. W każdej z nich powtarza się schemat kilku podstawowych składników: wezwanie do Boga/YHWH, skarga, obejmująca opis sytuacji cierpiącego, prośba o ratunek, argumenty skłaniające Boga do udzielenia pomocy, wreszcie pewność wysłuchania (obecna tylko w niektórych psalmach) połączona $\mathrm{z}$ obietnicą uwielbienia Boga ${ }^{9}$. Interpretacje psalmów obfitują w obszerne i wyczerpujące analizy ich kontekstualnego usytuowania zarówno w odniesieniu do środowiska życiowego (Sitz im Leben), jak i specyficznego układu literackiego. Znacznie trudniejsze jest pytanie natury egzystencjalnej: na jakiej drodze dokonuje się zmiana nastroju psalmisty z osoby skarżącej się na swój los, ogarniętej smutkiem lub rozpaczą, w kogoś wyznającego ufność w zbawczą moc Boga i przenikniętego radością? ${ }^{10}$ I czy ta zmiana nie jest iluzoryczna, lecz ma 'empiryczne' podstawy, czy cierpiący nie oszukuje sam siebie wmawiając sobie, że Bóg go wysłuchał? Skąd czerpie pewność? ${ }^{11}$

\section{Skarga jako odzwierciedlenie sytuacji granicznej}

Sytuacja graniczna pojawia się w jakimś momencie czyjejś historii życia jako zerwanie podstawowej ciągłości czasowej, która konstytuuje ludzką tożsamość. Co się dzieje, pyta Shlomith Rimmon-Kenan, znana z badań w zakresie narra-

7 Por. T.C. Ham, Songs of Brokenness to the Healing God, s. 233.

8 P. Ricoeur, Filozofia osoby, s. 55.

9 Por. C. Westermann, The Role of Lament in the Theology of the Old Testament, s. $20-38$.

10 Por. S.-H. Lee, Lament and the Joy of Salvation in the Lament Psalms, s. 224-247.

11 Por. Ch. O. Schroeder, History, Justice and the Agency of God. A Hermeneutical and Exegetical Investigation on Isaiah and Psalms, s. 83-108. 
cyjnych struktur życia, kiedy teraźniejszość w cierpieniu okazuje się tak różna od przeszłości, że podmiot doświadcza siebie jako kogoś 'innego, 'obcego'? Jak dalece niepewność w odniesieniu do przyszłości lub jej blokada, wpływa na 'tożsamość' cierpiącego? Jak ktoś przeżywając chorobę, czy jakąś inną poważną dolegliwość radzi sobie z zerwaniem łączności z poprzednimi etapami życia? I wreszcie, jak ktoś rekonstruuje swoją opowieść o sobie w następnie kryzysu tożsamości spowodowanego cierpieniem? Czy ta odzyskana ciągłość zostaje zastąpiona dwudzielną opowieścią, zbudowaną z tego, co było 'przed' i z tego, co nastąpiło 'po', z niedającą się pokonać przerwą między nimi? ${ }^{12}$ Powyższe pytania wykreślają mapę potencjalnych problemów, z jakimi trzeba się zmierzyć w sytuacji granicznej. Ale nie tylko. Próbując na nie odpowiedzieć, jednostka otrzymuje szansę opowiedzenia na nowo historii własnego życia z całkowicie innej perspektywy i już sam akt snucia tej opowieści może stać się jednym z ważnych sposobów radzenia sobie z konsekwencjami cierpienia.

Tym, co powoduje kryzys tożsamości, jest zaburzenie spójności konstytuującej zarówno opowieść jak i tożsamość. Rimmon-Kenan powołuje się na Petera Brooksa, psychoanalitycznie zorientowanego teoretyka literatury, który przekonuje o istnieniu ścisłego związku obu tych sfer, ujmując go w zwartej, łacińskiej maksymie: Mens sana in fabula sana. A zatem, zdrowie psychiczne wyraża się w spójnej historii życia, neuroza w niespójnej, pokawałkowanej historii, z zaburzoną chronologią ${ }^{13}$. Właśnie ciągłość jest jedną z form spójności, charakteryzującej zarówno opowieść jak i tożsamość narracyjną, tworząc jedność za pomocą łańcucha czasowo-logicznego, łączącego przeszłość, teraźniejszość i przyszłość. Przez różne rodzaje traumy ta jedność zostaje rozerwana, wprowadzając podmiot w doświadczenie chaosu, zagubienia i niepewności. Anthony Giddens widzi w nim odbicie lęku w sensie nadanym mu przez Kierkegaarda ${ }^{14}$. Z rutyny codziennych obowiązków wyziera niepokojąca możliwość, że ogarnie nas paraliżująca trwoga, sięgająca samych podstaw naszego zaufania w sensowność naszego bycia w świecie. Nie jest więc to jakiś rodzaj zamętu i powierzchownej dezorganizacji, lecz utrata poczucia samej realności rzeczy i osób. I co ważne w tym względzie, wbrew dominującym tendencjom we współczesnej psychoterapii, sposoby radzenia sobie $\mathrm{z}$ tym wszechogarniającym lękiem charakteryzują się bardziej emocjonalnym niż poznawczym

12 Sh. Rimmon-Kenan, The Story of 'I'. Illness and Narrative Identity, s. 10 (s. 9-27)

13 Ibidem, s. 12.

14 Por. S. Kierkegaard, Pojęcie lęku. Duński filozof rozważa pojęcie lęku w sensie psychologicznym, łącząc je z dogmatem grzechu pierworodnego, a więc odwołując się do tradycji biblijnej, ibidem, s. 20nn. 
aspektem ${ }^{15}$. Chodzi tu o zmianę emocjonalnego nastawienia do siebie samego i całości swego życia, a nie tylko o zwykłe racjonalne wyjaśnienie swego stanu. Oczywiście, zmianie nastroju towarzyszy nowa perspektywa poznawcza, ale jest ona bardziej ukierunkowana na nowe rozumienie siebie i swego losu niż na rozwiązanie problemu.

W opisach współczesnej kondycji podkreśla się, że trwoga egzystencjalna jest pierwsza i zaczyna określać naszą tożsamość już w momencie naszego pojawienia się na świecie. Poczucie bezpieczeństwa natomiast jest wtórne i nabyte. Ma charakter bazowy, ontologiczny, gdyż zostaje wypracowane we wczesnym dzieciństwie i wpisane w strukturę naszego bycia w wyniku interakcji z rodzicem lub opiekunem. Tym niemniej stanowi wartość dodaną, pozostając figurą na tle podstawowego lęku. A figura może, ale nie musi, przyjąć mniej lub bardziej zarysowaną postać w czyjeś historii życia. Owszem, może zasłonić lęk za pomocą nawykowych mechanizmów działania oraz rutynowych sposobów komunikowania się z innymi. Może jednak pozostawić go całkowicie odsłoniętym $^{16}$.

Sytuacja cierpienia przerywa bieg codziennych obowiązków i wystawia jednostkę na ataki lęku, konfrontując ją z pytaniami egzystencjalnymi, które wcześniej nie mogły dojść do głosu. Cierpienie, walka, wina, osamotnienie, śmierć zawierają w sobie granicę, mur nie do pokonania. Jako coś nieuchronnego, czego żadnymi konwencjonalnymi sposobami radzenia sobie nie da się uniknąć, prowadzą do kryzysu tożsamości i radykalnego zrewidowania prawdy o sobie ${ }^{17}$. W tym procesie konfrontowania się ze sobą w sytuacji granicznej, otwiera się, zdaniem Giddensa, możliwość odzyskania ontologicznego poczucia bezpieczeństwa, ale tylko w horyzoncie interpersonalnych relacji. Może ono przyjąć konkretny kształt ufności, nadziei i odwagi w nowych parametrach czasu, przestrzeni, ciągłości i tożsamości ${ }^{18}$.

Zanim jednak poprzez odzyskaną wiarę i męstwo bycia nastąpi transformacja tożsamości, cierpiący musi rozpoznać swoją sytuację jako sytuację graniczną. Nie potrafi tego zrobić bez pewnego rodzaju umiejętności samoobserwacji. Obejmuje ona serię szczegółowych pytań, dotyczących aktualnego usytuowania: Co się dzieje właśnie teraz? Co myślę? Co robię? Co czuję? Co się dzieje z moim ciałem (Jak oddycham?)? ${ }^{19}$ Przerywają one czasową i przestrzen-

15 Por. A. Giddens, Modernity and Self-Identity. Self and Society in the Late Modern Age, s. $36 \mathrm{nn}$.

16 Por. B. Wojdała, Sytuacja pacjenta jako sytuacja graniczna, s. 79n.

17 Por. ibidem.

18 Por. A. Giddens, Modernity and Self-Identity, s. 37n.

19 Por. ibidem, s. 78. 
ną ciągłość historii życia, tworząc próżnię, puste miejsce, oddzielone zarówno od przeszłości jak i przyszłości, zawieszając także teraźniejszość. To, co uderza w doświadczeniu cierpienia, przeżywanego w relacji do innych ludzi, to niezwykle mocno zarysowany wymiar odizolowania. Paul Ricoeur wyróżnia w nim cztery poziomy: 1. Cierpienie jest tak dalece własnym doświadczeniem, że nie można go zastąpić cierpieniem innych. Choć wszyscy cierpimy, to moje cierpienie jest jedyne i niepowtarzalne. 2. W moim cierpieniu nikt nie może mnie zrozumieć ani pomóc, jestem w nim całkowicie samotny. 3. Cierpienie powoduje, że inni, nawet najbliżsi jawią się jako moi wrogowie, a ich zachowania odbieram jako dodawanie mi cierpienia. 4. Wreszcie, cierpienie staje się najgłębsze, gdy zaczynam myśleć, iż zostałem wybrany, aby cierpieć, po prostu skazany na nie. Wtedy pojawiają się pytania: dlaczego ja, dlaczego mnie to spotyka? ${ }^{20}$

Osamotnienie w cierpieniu powoduje, że cierpiący traci zdolność działania, drastycznie zmniejsza się też pole jego aktywności. Pozostaje mu jedynie doznawanie cierpienia - passio. Ricoeur opisując ten stan z wielorakiej perspektywy, zwraca szczególną uwagę na niemożność w mówieniu, które często ogranicza się do krzyku i łez. A właśnie mówienie spośród wszystkich innych sprawności jest jedynym sposobem wyrażenia cierpienia, dlatego przyjmuje ono kształt skargi, która jednocześnie wypływa z głębi sytuacji cierpienia i kieruje się ku innemu jako wołanie o pomoc ${ }^{21}$. W odniesieniu do kryzysu tożsamości, do całości życia, skarga z jęku i prośby o ratunek, kiedy on nie nadchodzi, przekształca się w skargę na ..., w skargę przeciwko ... ${ }^{22}$. Zmienia się jej retoryczna szata w zależności od miejsca w odmiennych konfiguracjach narracyjnych, obejmujących nie tylko samą chorobę lub tragiczne przeżycia, ale także oddziaływanie cierpienia na rozumienie swego losu.

Jak ważna jest skarga w odzyskiwaniu narracyjnej spójności życia w sytuacji cierpienia, pokazują zachowania ludzi zmuszonych przez okoliczności zewnętrzne do biernej akceptacji swego cierpienia bez skargi. Kiedy jednak wreszcie dochodzi do głosu, przeprowadza ona cierpiącego przez kolejne etapy jego życia aż do pełnego wyrażenia siebie w opowiadaniu autobiograficznym. A. Giddens podkreśla jego terapeutyczną funkcję, wskazując na jego zdolność korygowania przeszłości i zawartych w niej doświadczeń emocjonalnych. Skarga w swoich różnorodnych formach ekspresji wychwytuje je i włącza w struk-

20 P. Ricoeur, Filozofia osoby, s. 57.

21 Ibidem, 58. Dobrym biblijnym przykładem zdolności mówienia zredukowanego do krzyku jest Wj 2,23, gdzie sytuacja ucisku Izraelitów w Egipcie staje się nie do zniesienia, przeradzając się w głośny jęk unoszący się z głębi ich cierpienia do Boga.

22 P. Ricoeur, Filozofia osoby, s. 60. 
turę narracji. W tej swoistej samoterapii odbywa się dialog z czasem, w którym cierpiący konfrontuje się z pytaniami, jak radzi sobie z czasowym wymiarem swego losu, jak widzi swoją przeszłość, czego oczekuje od swej przyszłości, jaki ma stosunek do swej teraźniejszości. Czas życia przestaje być skończonym zbiorem chwil, które bezpowrotnie mijają i nad którymi nie mamy żadnej władzy, co może rodzić poczucie beznadziejnego pogodzenia się $\mathrm{z}$ brakiem pomocy. Trwanie w dialogu z czasem oznacza identyfikowanie wydarzeń i sytuacji, które spowodowały lub powodują cierpienia i wzięcie za nie odpowiedzialności ${ }^{23}$.

\section{Skarga w strukturze narracyjnej Ps 6}

Spośród pięciu lamentacji (Ps 3-7), otwierających pierwszą księgę Psałterza (Ps 3-41), w Ps 6 zmiana nastroju w formie przejścia od skargi do ufności jest najbardziej widoczna ${ }^{24}$. Sama skarga zajmuje prawie całą przestrzeń psalmu (ww. 2-8), w jakimś stopniu obecna jest również na końcu, kiedy psalmista odnosi się do swoich wrogów (ww. 9-11) 25 $^{25}$ Tak rozbudowana musi zatem odgrywać niezmiernie ważną rolę $\mathrm{w}$ strukturze lamentacji, nie tylko $\mathrm{w}$ opisie sytuacji cierpienia, ale też $\mathrm{w}$ sposobach, w jakich psalmista je przeżywa i w jakich zmienia się jego rozumienie siebie ${ }^{26}$.

Starsze komentarze widzą w Ps 6 szereg tradycyjnych, konwencjonalnych wyrażeń, spotykanych także $\mathrm{w}$ innych lamentacjach. W nowszych odczytaniach, zwraca się uwagę na jego specyficzny i dobrze przemyślany układ literacki $^{27}$. Jeśli jednak panuje zgoda co do wyodrębnienia jego końcowej części,

23 Por. A. Giddens, Modernity and Self-Identity, s. 73.

24 Por. W. Brueggemann, W. H. Bellinger, Jr, Psalms, s. 48.

25 Por. S. Łach, Księga Psalmów, s. 117n.

26 C. Westermann w ciągle aktualnym i cytowanym artykule The Role of Lament (zob. przypis 9) wykazuje daleko idące podobieństwo w układzie podstawowych elementów między strukturą lamentacji a Wj 1-15, które jest opowiadaniem o wyzwoleniu Izraelitów z ucisku w Egipcie, z istotną rolą skargi w Wj 2,23-25, zwieńczonym hymnem uwielbienia w Wj 15. Zasadne jest zatem mówienie o strukturze narracyjnej lamentacji, gdyż odzwierciedla ona charakterystyczną dla narracji zmianę w czasie i dokonujące się przejście z jednej sytuacji w drugą. Lamentacje indywidualne można więc interpretować jako teksty poetyckie, opisujące tożsamość narracyjną osoby znajdującej się w sytuacji granicznej. Dobrym przykładem tego rodzaju egzegezy jest G. Pemberton, Hurting with God: Learning to Lament with Psalms; M.E.L. Hall, Suffering in God's Presence: The Role of Lament in Transformation, s. 219-232; T.C. Ham, Songs of Brokenness to the Healing of God, s. 233-246.

27 C. C. Broyles, The Conflict of Faith and Experience in the Psalms. A Form-Critical Study, s. 182. 
wyrażającej pewność wysłuchania przez Boga (ww. 9-11), to w odniesieniu do wierszy 2-8 spotkać się można $\mathrm{z}$ różnymi propozycjami podziału. Z punktu widzenia struktury narracyjnej psalmu, w której konstrukcją nośną całej kompozycji jest ruch od skargi do ufności i uwielbienia, istotnym jest ustalenie momentu zwrotnego, do którego prowadzi początkowa prośba i od którego następuje stopniowa zmiana postawy w kierunku pewności wysłuchania. Pomocą może tu posłużyć rozkład imienia Bożego YHWH, które tworzy interpersonalne ramy skargi: TY Boga i Ja psalmisty. Pięciokrotnie występuje ono w prośbach (ww. 2-5) oraz trzykrotnie jako podmiot czasowników wysłuchat (ww. 9.10) i przyjął (w. 10). Uderza jego nieobecność w ww. 6-8, opisujących sytuację cierpienia. Tak więc z perspektywy relacji psalmisty do YHWH układ psalmu byłby następujący: prośba skierowana do YHWH (ww. 2-5), opis sytuacji cierpienia psalmisty (ww. 6-8), pewność wysłuchania i przyjęcia modlitwy przez YHWH (ww. 9-11) ${ }^{28}$. Jednak wiersze 5 i 6 wydają się być ze sobą powiązanie zarówno na płaszczyźnie gramatycznej jak i semantycznej za pomocą partykuły kî̀, (bo, ponieważ). Wiersz 5 zawiera ostatnią prośbę, znacznie różniąca się od poprzednich nie tylko emocjonalną natarczywością (Powróć PANIE), ale także doborem słownictwa sytuującym psalmistę wewnątrz wspólnoty przymierza ${ }^{29}$. Z kolei wiersz 6 rozpoczyna się właśnie od $k \hat{\imath}$, wprowadzając motywację wcześniejszej prośby. Co więcej, przywołuje on sytuację śmierci jako nieuniknionego horyzontu cierpienia. Zaraz potem, w następnych wierszach (7-8), przedstawia on jej dramatyczne konsekwencje, lecz bez odniesienia do imienia Boga. Tym samym, w wierszach 5-6 dokonuje się przejście od prośby skierowanej do YHWH jako partnera przymierza, do prawdy o swojej sytuacji, która zmierza do śmierci, jeśli nie przyjdzie On z pomocą. I choć już do końca psalmu nie ma żadnej wzmianki o Jego konkretnej interwencji, to trzykrotnie zasygnalizowana pewność wysłuchania musi odzwierciedlać zmianę $\mathrm{w}$ postawie psalmisty.

Z tej krótkiej analizy wyłania się następująca struktura narracyjna psalmu: prośba rozpoczynająca się inwokacja do YHWH (2-4), wezwanie YHWH do działania w obliczu nadchodzącej śmierci motywowane więzia przymierza (5-6), odsłonięcie tożsamości cierpiącego w sytuacji granicznej (7-8), ufność mimo obecności wrogów wynikająca z pewności wysłuchania przez YHWH (9-11). W szczegółowym rozczytaniu tej struktury należy wydobyć rzeczywiste, egzystencjalne przesłanki, uzasadniające zmianę nastroju psalmisty z osoby ogarniętej lękiem w sytuacji cierpienia w osobę pełną ufności, zdolną przeciw-

28 Por. W. Brueggemann, W. H. Bellinger, Jr, Psalms, s. 50.

29 Por. S.-H. Lee (Lament and the Joy, s. 229nn), dla którego użycie terminu hesed wyraźnie wskazuje na miłość i wierność YHWH wynikającą z przymierza. 
stawić się swoim wrogom. Chodzi zatem o to, jak zmienia się narracyjna tożsamość cierpiącego w miarę przeobrażania się skargi z prośby przez opis jego sytuacji do pewności wysłuchania.

Pierwsze dwie prośby w w. 2 poprzedzone są inwokacją imienia YHWH i mają negatywną formę: PANIE, w twoim gniewie nie karć mnie, w swej zapalczywości nie doświadczaj mnie. Bezpośrednie zwrócenie się psalmisty do YHWH przyjmuje postać apostrofy ${ }^{30}$. W swoim podstawowym znaczeniu zakłada ona, odwrócenie się od aktualnych słuchaczy i zwrócenie się do kogoś spośród zebranych lub kogoś nieobecnego, zawieszając w ten sposób relacje z pozostałymi osobami, które mogą odczuwać w tym momencie pewien dyskomfort lub zażenowanie. Każde bezpośrednie wezwanie Boga w modlitwie posiada status apostrofy i oznacza wyłączenie wszystkich innych więzi komunikacyjnych, prócz tej jednej, z Bogiem ${ }^{31}$.

W lamentacji indywidualnej, inaczej niż w zbiorowej, która dopuszcza obecność innych, nie ma nikogo, od kogo psalmista, zwracając się do Boga mógłby się odwrócić. ${ }^{32}$ Jaką więc rolę pełni tu inwokacja? Psalmista staje całkowicie samotnie przed YHWH jako Kimś, do kogo może przyjść ze swoim cierpieniem, gdyż wszystkie wcześniejsze próby poradzenia sobie, łącznie z pomocą od innych, zawiodły. W tym sensie inwokacja spełnia podwójną funkcję. Owszem, rozpoczyna psalm, ale nie rozpoczyna dramatu cierpienia, które od jakiegoś czasu już trwa, wpychając cierpiącego w coraz głębszą beznadziejność. Nie mając znikąd wsparcia, psalmista zwraca się do Boga jako jedynego punktu odniesienia. Jednocześnie jednak odwraca się od siebie i swojej sytuacji, przypisując właśnie Jemu przyczynę swego cierpienia. Przeżywa je jako wyraz gniewu Boga, na podstawie którego tradycja chrześcijańska włączyła Ps 6 do zbioru siedmiu psalmów pokutnych, choć nie zawiera on żadnego wyznania grzechów $^{33}$. Ta pierwsza postać skargi, skargi na $Y H W H$, na Jego niewytłumaczalną zapalczywość, odzwierciedla poczucie winy, które jest jednym z najtrudniejszych doświadczeń cierpienia. Sytuuje bowiem cierpiącego pod pręgieżem oskarżenia i każe mu myśleć, że zasługuje na cierpienie jako karę za grzechy.

30 Jako środek retoryczny w mniejszym stopniu przekazuje ona jakieś treści, w większym - emocje. Jej zastosowanie wykracza poza zwykłe sposoby komunikowania się z innymi, zwracając uwagę na mówiącego i na to, co się z nim dzieje, por. J. Culler, Apostrophe, w: idem, The Pursuit of Signs, s. 139.

31 Por. G. Hopps, Beyond Embarrassment: A Post-Secular Reading of Apostrophe, s. 224-241 (dostęp: DOI: 10.3366/rom.2005.11.2.224).

32 Nawet wirtualna, a więc wyobrażona obecność potencjalnych słuchaczy lub czytelników, byłaby zakłóceniem wyłącznej relacji z Bogiem, ustanowionej przez inwokację, pozbawiając modlitwę czystości intencji.

33 Por. W. Brueggemann, W. H. Bellinger, Jr, Psalms, s. 53. 
Poczucie winy czyni cierpienie niemym i zamyka w kręgu samopotępienia. Może go rozerwać jedynie krzyk-prośba o zaprzestanie karcenia. Przełamuje ona niemożność mówienia, przenosząc oskarżenie na Boga, torując przez to drogę do drugiej postaci skargi w ww. 3-4: Zmiłuj się nade mną PANIE, bom ja słaby, ulecz mnie PANIE, bo drża moje kości a dusza moja bardzo strwożona, Ty zaśo PANIE, jak długo...?

Semantyka tych wierszy zbudowana jest na osi relacji $T Y$ Boga, z trzykrotnym użyciem imienia YHWH i ja psalmisty. Zastanawia przejście od oskarżenia w poprzednim wierszu do prośby o Jego zmiłowanie, po której jednak nie następuje przyznanie się do grzechów (jak np. w Ps 51,3). Psalmista zna nie tylko zagniewanego Boga, ale i miłosiernego. Gniew i miłosierdzie idą w parze, co jest najbardziej widoczne w epizodach, związanych ze złotym cielcem w Wj $32-34$. A zatem w sekwencji wierszy $2-4$, cierpienie jest przeżywane w ramach teologii przymierza. Obrazy Boga ukazane w Księdze Wyjścia kształtują doświadczenie psalmisty i wpływają na sposób, w jaki postrzega on swoją sytuację $e^{34}$.

Ponieważ miłosierdzie Boga jest większe od Jego gniewu, psalmista zaczyna dostrzegać w cierpieniu siebie samego i to co się z nim dzieje. Najpierw pojawia się ‘ja' w słabości, potem drżące 'kości' i wreszcie strwożona 'dusza'. Ukazuje się dramat cierpienia, obejmujący całą osobowość psalmisty, od fizycznych niedomagań odzwierciedlających niezdolność do działania (por. Ne 3,34), przez kryzys tożsamości po przenikający do głębi lęk. Odsłonięty obszar cierpienia przedłożony jest Bogu, który znowu przywołany jest w inwokacji, ale $\mathrm{w}$ formie wzmocnionej. Imię YHWH poprzedzone jest zaimkiem osobowym TY, który wiąże cierpienie psalmisty z aktualną i bezpośrednio odczuwaną obecnością Boga. Ale za inwokacją nie podąża żadna prośba, tylko niedokończone pytanie o czas: jak dtugo...?

To na wskroś egzystencjalne i otwarte pytanie ma podwójny wektor czasowy. Kieruje się w przeszłość i odnosi się długotrwałości cierpienia. Psalmista dochodzi do momentu, w którym wydaje mu się, że już dłużej nie wytrzyma. Ale ponieważ zwraca się do YHWH, to odnosi się ono także do przyszłości i oznacza oczekiwanie na Jego działanie, które jednak ciągle nie nadchodzi. Owo przedłużające się nie-działanie Boga przechodzi w doświadczenie Jego nieobecności ${ }^{35}$, nadając skardze nową postać i uzasadniając treść ostatniej prośby w ww. 5-6: Powróć PANIE, ocal moje życie, wybaw mnie ze względu na Twa wierność, bo w śmierci nie ma pamięci o Tobie, w Otchłani któż Cię wychwala?

34 Por. W. Brueggemann, The Psalms and the Life of Faith, s. 26n.

35 Por. Ps 13,2-3, gdzie występuje seria czterech podobnych pytań, zob. Ch. O. Schroeder, History, Justice and the Agency of God, s. 93nn. 
To punkt zwrotny skargi. Definiuje on na nowo nie tylko samo cierpienie, ale także sposób postrzegania Boga. Cierpienie i Bóg przeżywane są teraz wewnątrz wspólnoty przymierza, której najmocniejszym znakiem jest użyte tu słowo wierność (hesed). Właśnie ze względu na łaskawa i nieodwołalna wierność Boga, zagwarantowaną Jego przymierzem możliwe jest wołanie o Jego powrót i interwencję. Cierpienie nie musi zatem być bezkształtnym jękiem, może przyoblekać się w skargę pouczona przez teologię przymierza. Nie jest ona iluzją karmiącą cierpiącego łatwym i przez to iluzorycznym i fałszywym pocieszeniem. Lamentacje biblijne dalekie są od tego. Przeciwnie, odwołując się do wierności Boga, można dojść do nagiej prawdy cierpienia, kiedy stawia ono na krawędzi śmierci. Psalmista łączy ją z Jego nieobecnością. Znajduje tu więc odzwierciedlenie taki rodzaj osobistej relacji z Bogiem, w której Jego obecność naprzemiennie przeplata się z Jego nieobecnością. Cierpienie mające postać sytuacji granicznej wymazuje wcześniejsze doświadczenie bliskości Boga, skłaniając psalmistę do poszukiwania Go w innym, nieznanym mu poprzednio wymiarze życia. Dlatego językowy kształt skargi zmienia się, przechodzi ona w opis sytuacji cierpienia, ale bez odniesienia do imienia YHWH (ww. 7-8): Zmęczyłem się moim jękiem, co noc zraszam płaczem moje łóżko, łzami rozpuszczam moje posłanie. Moje oko marnieje w udręce, znużone z powodu wszystkich moich przeciwników.

Skarga dochodzi tu do swego kresu, zmierzając do ostatecznego wypełnienia swego zadania. Odsłania bowiem cierpienie w jego najbardziej tragicznej nucie, bez upiększeń, łatwych pocieszeń i racjonalnych wyjaśnień. Oczyszcza je ze zbędnego patosu i pokazuje w nagiej prawdzie ${ }^{36}$. Jego przeżywanie sprowadzone jest do krótkich odcinków czasu. Każdej nocy przeżywa je w ukryciu i samotności. Zatrzymuje się na obrazie łóżka zroszonego łzami, których nikt nie ociera, oko powtarzającym się co noc płaczem coraz bardziej się nuży. A w końcu pod nieobecność Boga obecni są tylko wrogowie. Skarga zbliża się tu do granicznego punktu izolacji w cierpieniu, kiedy inni ludzie jawią się jako nieprzyjaciele. Tradycyjna pobożność nie radzi sobie właśnie z całkowitym osamotnieniem cierpienia, z opuszczeniem przez Boga, próbując mu nadać chyba zbyt pośpiesznie jakiś sens lub zbawczą wartość. W opisie sytuacji granicznej w ww. 7-8 nie ma bezpośrednio odczuwanej obecności Boga. Psalmista cierpi całkowicie samotnie na swoim posłaniu, pod osłoną nocy, bez wsparcia ze strony kogokolwiek, wręcz przeciwnie, w obliczu wrogości swoich przeciwników. Jak to więc możliwe, że dokonuje się radykalna zmiana w postawie cierpiącego, i to wobec swoich prześladowców, która pozwala mu w końcowych wierszach psalmu, wyznać pewność wysłuchania przez YHWH (9-11): Odejdźcie od mnie

36 Por. M. E. L. Hall, Suffering in God's Presence, s. 226n. 
wszyscy czyniący nieprawość, bo PAN ustyszał głos mojego płaczu. Wysłuchał PAN moje błaganie. PAN przyją moja modlitwę. Niech się zawstydzą i zatrwożą bardzo wszyscy moi wrogowie, niech zawróca, zawstydza się natychmiast.

Czy owo trzykrotne użycie imienia YHWH nie jest w jakiejś mierze zaklinaniem rzeczywistości i wmawianiem sobie, że Bóg faktycznie usłyszał Jego skargę? Problematyczność tego wyznania jest tym większa, że w odróżnieniu od innych lamentacji, między opisem sytuacji cierpienia a pewnością wysłuchania rozciąga się przepaść, nie zapośredniczona żądną prośbą czy aktem ufności (por. np. Ps 13) ${ }^{37}$. W wyjaśnieniach tego problemu proponuje się zazwyczaj interpretację kultyczną. Przejście od smutku do radości mogło nastąpić pod wpływem wyroczni zbawienia wygłoszonej przez kapłana, co zakłada pobyt cierpiącego w świątyni (por. 1 Sm 1,9-18). Ps 6 nie zawiera jednak żadnej wskazówki odnoszącej się do sanktuarium ${ }^{38}$.

Ostatni etap skargi w ww. 7-8 wskazuje na doświadczenie cierpienia w osamotnieniu, na własnym łóżku, a więc nie tylko poza sferą publicznego kultu, lecz także w izolacji społecznej. Dlatego zmiany nastroju psalmisty należy szukać w narracyjnych przekształceniach skargi jako siły odpowiedzialnej za transformację jego tożsamości. Dynamicznej strukturze skargi odpowiada równie dynamiczna struktura pewności wysłuchania w ww. 9-10. Z tego względu, końcowe wyznanie psalmisty może świadczyć o skuteczności jego skargi, która ukazuje się w nowym świetle z perspektywy odzyskanej ufności w YHWH.

Imię YHWH występuje tu jako podmiot czasowników stuchać i przyjąć w zdaniu uzasadniającym wezwanie skierowane do jego wrogów. Ich znaczeniem rządzą terminy, definiujące retrospektywnie skargę jako głos mojego płaczu, moje błaganie, moja modlitwa. To nie są synonimy. Ich sekwencja odzwierciedla językowe przeobrażenia skargi, od pozbawionego słów płaczu, przez żarliwość błagania, aż po ujętą w słowa modlitwę. Widać tu wysiłek psalmisty, aby swoje cierpienie nie tylko po prostu wykrzyczeć (pierwszy stadium skargi), ale także, by je $w$ pełni wyartykułować w horyzoncie śmierci (drugie stadium skargi), i wreszcie, żeby je wypowiedzieć w całej jego prawdzie (trzecie stadium skargi). Zmienia się również sens czasowników, opisujących postawę Boga wobec cierpiącego. Początkowe ustyszał znajduje dopełnienie w przyjął. Nie przedstawiają więc one stopniowego zbliżania się Boga. Ruch odbywa się w przeciwnym kierunku: to cierpienie ujęte w potrójną formę skargi-modlitwy wznosi się do Niego i jest przezeń przyjęte (zgodnie z Wj 2,23).

37 Por. J. Becket, Lament in Three Movements: The Implications of Psalm 13 for Justice and Reconciliation, s. 207-218, zwł. s. 212nn.

38 Por. S. Łach, Księga Psalmów, s. 117n.; Ch. O. Schroeder, History, Justice and the Agency of God, s. 85nn. 
Na czym ostatecznie polega skuteczność skargi w Ps 6? Rozstrzygający jest tutaj opis sytuacji cierpienia jako sytuacji granicznej. Psalmista nie wyraża tutaj po prostu swego cierpienia, ale w opuszczeniu przez Boga przedkłada Mu siebie jako osobę cierpiącą. Tym samym Bóg nie tyle przyjmuje jego modlitwę, ile w modlitwie jego samego, przenikniętego cierpieniem ${ }^{39}$. I to właśnie przyjęcie przez Boga, stojące na przeciwległym biegunie odrzucenia przez Jego gniew w w. 2 skutkuje pewnościa wysłuchania, której paradoksalny charakter podkreśla wstyd ogarniający jego nieprzyjaciół i ich odwrócenie się od cierpiącego (w. 11). Istotną konsekwencją tej zmiany w tożsamości psalmisty jest odzyskanie utraconej w sytuacji cierpienia godności i szacunku do samego siebie ${ }^{40}$. W takim też znaczeniu można mówić o terapeutycznej funkcji skargi.

\section{Podsumowanie}

Ps 6 nie należy do typowych przykładów lamentacji w Księdze Psalmów, gdyż brakuje w nim kilku elementów, charakterystycznych dla tego gatunku literackiego. Jego wyjątkowość wynika z faktu, że składa się on wyłącznie ze skargi, w którą wplecione są prośby, i z pewności wysłuchania, występującej zaraz po opisie sytuacji cierpienia. Dlatego przejście w tym psalmie od skargi do ufności tak bardzo zastanawia, stawiając pytania nie tylko o jego empiryczne podstawy, ale także o prawdopodobne od strony psychologicznej i teologicznej, jego uzasadnienie.

Przeskok w strukturze literackiej od skargi do ufności odzwierciedla zmianę w czasie w tożsamości cierpiącego, a tę może adekwatnie opisać tylko struktura narracyjna. Stosowana w tradycyjnej egzegezie krytyka form, czy nawet krytyka redakcji nie potrafi oddać wszystkich przeobrażeń skargi, mających postać trajektorii, i poruszającej się na planie psychologicznym od różnych objawów cierpienia do ufności w Bogu, a na płaszczyźnie teologicznej i egzystencjalnej od całkowitej dezorientacji do nowej, pouczonej przez skargę orientacji.

Tym samym poprzez swoją specyficzną gramatykę i retorykę, skarga oddziałuje na tożsamość cierpiącego. Jej narracyjny kształt posiada cechy charakterystyczne dla dobrze skomponowanej fabuły: początek przedstawia problem, środek - punkt zwrotny, wreszcie koniec zawiera rozwiązanie. Stąd układ narracyjny Ps 6 biegnie od początkowej prośby wyrażającej przeświadczenie

39 W żadnym innym psalmie, termin modlitwa (tephilah) nie występuje jako dopełnienie czasownika przyjąć (laqah), najczęściej z czasownikiem stuchać i jego synonimami.

40 Por. P. Ricoeur, Filozofia osoby, s. 59. 
cierpiącego, że Bóg go odrzucił w swoim gniewie (ww. 2-4), przez punkt zwrotny w wezwaniu o bezpośrednią interwencję YHWH (ww. 5-6), do odsłonięcia siebie w prawdzie sytuacji granicznej (ww. 7-8). Ten ruch ma kierunek od tego, co zewnętrzne, do tego, co wewnętrzne. I dopiero teraz następuje przeskok, do tego, co wyższe - Boga, przyjmującego w skardze cierpiące 'ja' psalmisty (ww. 9-11).

Wszystkie te narracyjne przeobrażenia skargi umieszczone są wewnątrz dialogicznej relacji z Bogiem i wydają się niemożliwe poza nią. Stąd skarga, choć w niektórych psalmach zbliża się niebezpiecznie do krawędzi rozpaczy (Ps 88), to we wszelkich swoich artykulacjach, właśnie dlatego, że jest przedłożona Bogu mimo opuszczenia przez Niego, uczy wytrwałego znoszenia cierpienia, kiedy nie można już w inny sposób z nim sobie poradzić.

\section{Bibliografia}

Becket J., Lament in Three Movements: The Implications of Psalm 13 for Justice and Reconciliation, Journal of Spiritual Formation \& Soul Care 9/2 (2016), s. 207-218

Broyles C. C., The Conflict of Faith and Experience in the Psalms. A Form-Critical Study, Sheffield 1989.

Brueggemann W., The Psalms and the Life of Faith, (ed. P. D. Miller), Minneapolis 1995. Brueggemann W., Bellinger W. H., Jr, Psalms, New York 2014.

Culler J., Apostrophe, w: tenże, The Pursuit of Signs, London 1981, s. 135-154.

Giddens A., Modernity and Self-Identity. Self and Society in the Late Modern Age, Stanford, California 1991.

Hall E. L., Suffering in God's Presence: The Role of Lament in Transformation, Journal of Spiritual Formation \& Soul Care 9/2 (2016), s. 219-232.

Ham T. C. T. C., Songs of Brokenness to the Healing God, Journal of Spiritual Formation \& Soul Care 9/2 (2016), s. 233-246.

Hopps G., Beyond Embarrassment: A Post-Secular Reading of Apostrophe, Romanticism 11/2 (2005), s. 224-241 (dostęp: DOI: 10.3366/rom.2005.11.2.224).

Jaspers K., Sytuacje graniczne, przeł. A Staniewska, M. Skwieciński, w: R. Rudziński, Jaspers, Warszawa 1978, s. 186-242.

Johnston P. S., The Psalms and Distress, w: Interpreting the Psalms. Issues and approaches, Johnston P. S., Firth D. G. (eds.), Leicester 2005, s. 63-84.

Kierkegaard S., Pojęcie lęku, Kęty 2000.

Lee S.-H., Lament and the Joy of Salvation in the Lament Psalms, w: The Book of Psalms: Composition and Reception, P. W. Flint. P. D. Jr Miller, A. Brunell, R. Roberts (eds.), Leiden, Boston 2005, s. 224-247.

Łach S., Ksiega Psalmów, Poznań 1990.

Mays J. L., A Question of Identity: The Threefold Hermeneutic of Psalmody, The Ashbury Theological Journal 41/1 (1991), s. 87-94. 
Pemberton G., Hurting with God: Learning to Lament with Psalms, Abilene, Texas 2012. Ricoeur, P., Filozofia osoby, Kraków 1992.

Rimmon-Kenan Sh., The Story of 'I'. Illness and Narrative Identity, Narrative 10/1 (2002), s. 9-27.

Schroeder Ch. O., History, Justice and the Agency of God. A Hermeneutical and Exegetical Investigation on Isaiah and Psalms, Leiden, Boston, Koeln 2001.

Westermann C., The Role of Lament in the Theology of the Old Testament, Interpretation 28 (1974), s. 20-38.

Wojdała B., Sytuacja pacjenta jako sytuacja graniczna, Psychoterapia 1/176 (2016), s. 77-86. 